IJMS 17 (1), 107-128 (2010)

\title{
ORGANISATIONAL COMMITMENT IN MALAYSIAN PUBLIC SECTOR
}

\author{
SHARIFAH NORAIDA SYED ZAINAL ABIDIN \\ MOHD SHALADDIN MUDA \\ FAUZIAH ABU HASAN \\ AHMAD MUNIR MOHD SALLEH @ EMBAT \\ Faculty of Management \& Economics \\ Universiti Malaysia Terengganu
}

\begin{abstract}
This paper describes a research project that aims to determine the level of civil servants' organisational commitment and the factors associated with it. The instruments used to measure organisational commitment, empowerment, job characteristics, and organisational communication were adapted from Allen and Meyer (1990), Spreitzer (1995), Hackman and Oldham (1975), and Downs and Hazen (1977). The findings demonstrated that civil servants appeared to have a higher level of affective commitment with mean value of 3.88 compared to continuance 3.58 and normative commitment 2.92. The study also found that civil servants were psychologically empowered in the department with mean value of 3.71 , had experienced a variable opportunity in job with mean 3.51 and were reported to be satisfied with the existing communication in the department with mean value of 3.68. Research findings also showed that there is a correlation between organisational commitment (affective, continuance, and normative commitment) with empowerment, job characteristics, and organisational communication variables. The stepwise regression exhibited that empowerment variable is the most dominant predictor of civil servants' organisational commitment. Meanwhile, organisational communication variable appeared to be the most significant factor to influence civil servants' affective commitment. Civil servants with continuance commitment were found to be best predicted by empowerment variable. Finally, civil servants with normative commitment tend to be mostly influenced by job characteristics variable.
\end{abstract}

Keywords: Organisational commitment; empowerment; job characteristics; organisational communication.

\section{ABSTRAK}

Makalah ini menerangkan tentang projek kajian yang bermatlamat untuk menentukan tahap komitmen organisasi penjawat awam dan faktor-faktor yang 
berkaitan dengannya. Alat pengukuran bagi komitmen organisasi, pemberian kuasa, ciri-ciri pekerjaan dan komunikasi dalam organisasi telah diadaptasi daripada 'Allen et al. (1990), Spreitzer's (1995), Hackman et al. (1975) dan Down et al. (1977). Dapatan kajian menunjukkan penjawat awam memiliki komitmen afektif yang lebih tinggi dengan nilai min 3.88 berbanding berterusan 3.58 dan normatif 2.92 . Kajian juga mendapati penjawat awam secara psikologinya telah diberi kuasa dalam jabatan dengan nilai min 3.71, pernah merasai pelbagai peluang dalam pekerjaan dengan nilai min 3.51 dan dilaporkan berpuas hati dengan komunikasi yang wujud dalam jabatan tersebut dengan nilai min 3.68. Dapatan kajian juga menunjukkan terdapat kolerasi antara komitmen organisasi (afektif, berterusan dan normatif) dengan pemboleh ubah pemberian kuasa, ciri-ciri pekerjaan dan komunikasi dalam organisasi. Analisis regresi 'stepwise' memperlihatkan pemboleh ubah pemberian kuasa sebagai faktor paling dominan dalam meramalkan komitmen organisasi penjawat awam. Sementara itu, pemboleh ubah komunikasi dalam organisasi merupakan faktor yang paling penting dalam mempengaruhi komitmen afektif penjawat awam. Penjawat awam dengan komitmen berterusan didapati paling baik diramalkan oleh pemboleh ubah pemberian kuasa. Akhir sekali, penjawat awam dengan komitmen normatif paling cenderung dipengaruh oleh pemboleh ubah ciriciri pekerjaan.

Kata Kunci: Komitmen organisasi; pemberian kuasa; ciri-ciri pekerjaan; komunikasi dalam organisasi.

\section{Introduction}

Previous studies had proven that having committed employees are very essential for organisations as they can increase their work performance (Shortland, 2005) as well as their profit, lower employees' turnover rate (Allen \& Meyer, 1990), and also intention to leave (Rajendran \& Raduan, 2005; Stallworth, 2003). From the context of the Malaysian public sector, as a central body in making national aspirations, goals, and objectives of Vision 2020 come to reality, the government needs civil servants who have high integrity, are proficient and professional in doing work, able to face any - challenges, and possess positive work attitudes. Civil servants are stated to have high professionalism in work when they have a deep commitment to the organisation and at the same time are willing to put full effort in achieving organisational goals (Mohd Najib, 2006).

Due to this, many programmes were conducted by the government to change the attitudes of their civil servants. "Clean, Efficient, and Trustworthy" was one of the concepts that was introduced by the government in order to build positive work ethics and good moral values among civil servants (Ahmad Atory, 2005). From the context of human resource management itself, the 


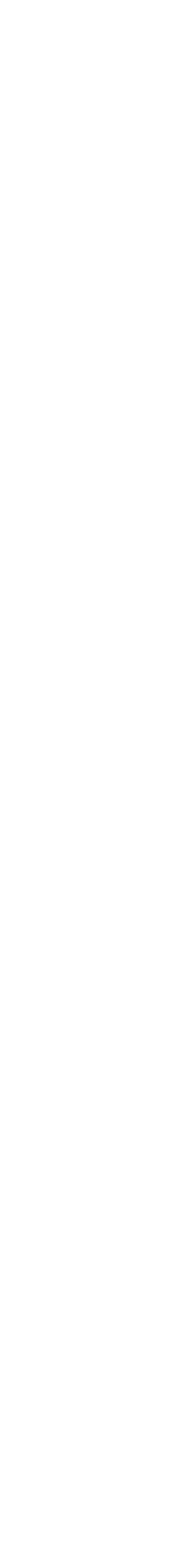

latest effort that has been adopted by the government was through the implementation of five components of performance management, which are 1) strategic direction, 2) organisational capacity, 3) people potential, 4) workforce performance, and 5) work culture (Malaysia, 2005).

All the strategic actions that have been taken through this implementation of five components of performance management play an important role in changing civil servants' work attitude. According to Jones et al. (1996) and Nixon (1994), changing the management from controlling to enabling; employees not only can contribute more but also able to achieve organisational goals as well as solve problems related to it. Apart from that, it can give a sense of control over their own work as they do not have to wait and rely on management's decision (Brewer, 1997).

Previous studies also reported that the job dimensions of employees involved are among the most important variable in predicting commitment (Ugboro, 2006; Kwon \& Banks, 2004; Colbert \& Kwon, 2000; Nijhof, De Jong, \& Beukhof, 1998). Positive personal values and work outcomes will be obtained when the job that employees possess have high levels of five core job dimensions; skill variety, task identity, task significance, task autonomy, and feedback.

Another element that can inculcate employees' commitment is through communication. Management needs to constantly communicate with their employees. It is stated that good communication that flows within the organisation can help employees understand and identify the responsibility that they carry out, as well as the expectations that are set on them. As opposed to that, factors such as lack of time, insufficient communication between management and employees, and misleading direction are encountered because of insufficient communication between management and employees, that can lead to employees' confusion on how to achieve goals, which in turn may affect the performance and commitment of employees (Hunt et al., 2000 \& Brewer, 1997).

\section{Problem Statement}

Despite a lot of programmes and strategies that have been taken seriously by the government to improve civil servants' work culture, there are still a lot of complaints about them. For example, Utusan Malaysia (2005, June 23) reported that about half of government officers and civil servants were reported not sincere and not fully committed in giving their best services to customers. They did not respond well to changing their work culture in line with the changes made by the government. Ishak (2005) claimed that the public sector's work culture nowadays is not based on the needs of the

IJMS 16 (2), 107-128 (2010) 
citizens, but more on the convenience of civil servants itself. Additionally, according to Behaviour and Discipline Report Year 2003, 5,553 or 0.45\% of civil servants were not disciplined because of misuse of power, being irresponsible, inefficient, always absent, not giving their best, not trustworthy, and being careless in their work (Mohtar, 2004). This unhealthy work attitude has tarnished the image of the Malaysian public sector. Not responding well to customer needs, being less efficient, not serious, and unprofessional in doing their tasks were among common negative perceptions that were thrown by citizens to civil servants.

Due to these issues, the commitment of civil servants therefore is essential and should be looked into seriously because in the Ninth Malaysia Plan, Thrust 5 (26); the efficiency of public service delivery system depends on the quality of public sector workforce. The success of the strategic direction to increase the efficiency of public service delivery system may only be accomplished if the civil servants were enthusiastic, committed, and excited about their work task (Mohd Najib, 2006).

Even though there are many studies conducted in the context of organisational commitment in Malaysia (Rajendran \& Raduan, 2005; Kamarul Zaman \& Raida, 2003; Razali, 1999), little attention is given to study the organisational commitment by the Malaysian public sector through the internal factors of empowerment, job characteristics, and organisational communication. Zakaria (2004) suggested that research in this area is needed and should be further explored by using non-monetary benefits such as empowerment, autonomy, and interesting job influences.

As had been discussed earlier, these elements were among the strategies that have been implemented by the government to change the attitude of civil servants. The strategies include engaging civil servants in organisational activities, empowering them, practising job enrichment, providing feedback, and establishing effective communication. These actions were implemented in order to increase the performance of civil servants as well as the Malaysian public sector itself. However, to date, not much is known about the perception that civil servants have regarding whether these - implementations can psychologically improve their work, increase their dedication, and engage them more to their organisation.

\section{Research Question}

Fundamentally, this study was aimed to examine the problems related to civil servants' organisational commitment and the factors associated with it. Some issues and questions that arise are summarised as follows:

1. What are the levels of civil servant organisational commitment (affective, continuance, and normative commitment), empowerment, job characteristics, and organisational communication? 
2. Are there any relationships between organisational commitment (affective, continuance, and normative commitment) and independent variables of empowerment, job characteristics, and organisational communication?

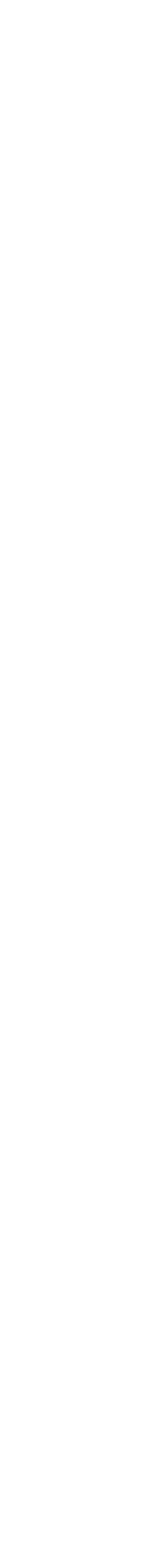

3. What is the most dominant variable that can influence organisational commitment (affective, continuance, and normative commitment)?

\section{Research Objective}

The specific objectives of the study are as follows:

1. To identify the levels of civil servant organisational commitment (affective, continuance, and normative commitment), empowerment, job characteristics, and organisational communication;

2. To measure the relationship between organisational commitment (affective, continuance, and normative commitment) and independent variables; and

3. To determine the most dominant variable influencing organisational commitment (affective, continuance, and normative commitment).

\section{Significance of the Study}

Even though there have been much research conducted in Malaysia using Allen and Meyer's (1990) Three-Dimensional Model of Organisational Commitment, not much consideration was given to specify the variables based on internal factors of empowerment, job characteristics, and organisational communication. Zakaria (2004) suggested that in order to get deeper understanding toward this construct, the multidimensional organisational commitment should be thoroughly explored and more empirical data is needed about the antecedents of each of this affective, continuance and normative commitment. By adapting the internal factors of work environment, this study therefore provides a different view of factors affecting organisational commitment as well as broadening the existing factors related to the Malaysian context.

From the management itself, the study can give a comprehensive picture pertaining to state civil servants' perception on empowerment, job characteristics, and organisational communication, and how these factors can affect their commitment. In accordance with the government efforts to encourage positive work attitude among civil servants, the findings of the study can give ideas for the management to take corrective action in upgrading the civil servants' engagement and attachment toward their workplace. It is significant for the management to identify and understand every single factor that can affect the level of its workforce commitment as from it, high performance and better quality of work can be achieved.

IJMS 16 (2), 107-128 (2010) 


\section{Literature Review}

\section{Organisational Commitment}

Organisational commitment can be considered as vitally important as through it, high profitability and productivity as well as high quality of work performance can be achieved. Downs and Hazen (1977) claimed that committed employees are the most important asset as it relates to loyalty to the organisation. It has been proven that employees who identify strongly with their organisation tend to be more concerned about their organisational reputation, survival, and success. Led by this attachment, they will give their best efforts in fulfilling the responsibility to achieve higher productivity, better quality work performance, as well as to increase the organisation's profits (Nijhof et al., 1998; Rousseau, 1998).

The organisational commitment term varies from one researcher to another. Referring to past literature, most of the developed theories or models were based on attitudinal and behavioural aspects. The former aspect is associated with employees' emotional or psychological attachment development toward their employers (Sheldon, 1971). Mathieu and Zajac (1990) viewed this attachment as an attitude that reflects the nature and quality of the linkage between both parties. Contrary to that, the later approach is linked with employees' commitment, which is related to their extra-role behaviour to act in a way that can make them meet organisational goals and interests (Wiener, 1982; Mowday, Steers \& Porter, 1979).

\section{Organisational Commitment and Empowerment}

One of the antecedent elements under the work environment that can inculcate and foster organisational commitment is the empowerment factor. In general, empowerment relates with a process of giving power to others, while in specific terms it can be defined as a process of granting autonomy to employees by way of allocating relevant information and the provision of control over factors affecting employees' work performance (Newstrom - \& Davis, 2002).

Commitment can occur through empowerment as it can produce psychological states that lead to positive consequences for the organisation, including willingness to engage in organisational citizenship, give extra role performance, promote satisfaction in job, and encourage motivation (Fornes \& Rocco, 2004). Through empowering, the organisation can improve its productivity as the process can strengthen employees' motivation in terms of providing them with the opportunity to attain intrinsic rewards from their work, such as greater sense of accomplishment and a feeling of importance.

112 IJMS 17 (1), 107-128 (2010) 
These sense of accomplishment and a feeling of importance automatically are linked to the employees' performance. A study by Liu, Fellows, and Chiu (2006) discovered that when the perception of work empowerment increases, employees' organisational commitment increases accordingly. The findings showed that the factors of access to opportunity and resources had enhanced self efficacy of employees to feel empowered, foster their motivation, and commitment before leading to increased work performance and effectiveness.

Another study by Dee, Henkin, and Duemer (2003) measured structural antecedents and psychological correlates of empowerment. Adapting psychological empowerment by Spreitzer (1995), the results demonstrated a significant association between meaning, self determination, impact, and the total empowerment score (meaning, competence, self determination, and impact) with organisational commitment. Respondents were reported to view their work as meaningful, have the ability and autonomy to control their own work, as well as have an impact on organisational outcomes. This increased task motivation would promote them to be strongly attached to the organisation, thus reduce the level of burnout and turnover among them. Correspondingly, a study by Batnagar (2005) on Indian managers' provided support for Dee et al. (2003). The findings had demonstrated psychological empowerment as an antecedent to respondents' engagement with the organisation, where affective commitment was found to be a strong outcome of psychological empowerment, followed by normative and continuance commitment. The linkages that occur proves that psychological empowerment does have an effect on employees' emotional attachment, identification, and involvement in the organisation, a sense of moral obligation to remain with the organisation, and the perception of the costs employees will be dealt with if they chose to leave the organisation.

\section{Organisational Commitment and Job Characteristics}

Another scope of determinant that affects organisational commitment is job dimension. Many previous studies indicated the dimensions of job employees involved as the most important variable in predicting commitment (Kwon \& Banks, 2004; Colbert \& Kwon, 2000; Nijhof et al., 1998). The well known theory related to the job dimensions is job characteristics theory by Hackman and Oldham (1975). The theory predicts on the assumption that individuals perceive and value a stable set of dimensions which their employment provides them with a variable opportunity for experience. The positive personal values and work outcomes are obtained when jobs have high levels of five core job dimensions of skill variety, task identity, task significance, task autonomy, and feedback. Additionally, three critical psychological states can occur in employees if jobs are designed in a way that can increase

IJMS 16 (2), 107-128 (2010) 
all of these dimensions. Firstly, the experience of meaningfulness in work is determined by the level of skill variety, task identity and task significance. Secondly, the experience of responsibility for work outcomes is determined by the amount of autonomy presented to employees. Finally, employees are provided with the knowledge of the performance of work activities that they are involved with. This is determined by the amount of feedback that employees receive after completing the work (Hackman \& Oldham, 1975).

Numerous studies provide empirical evidence for the positive relationship between organisational commitment with job characteristics and its subscales. For instance, a study by Dunham, Grube, and Castaneda (1994) showed a significant relationship between overall job characteristics with organisational commitment whereas the assessment within the subscales indicated only skill variety, task identity, and task significance were found to be related with organisational commitment. Another survey by Bhuain, Al-Shammari, and Jefri (2001) identified the influence of job characteristics on organisational commitment among expatriates in Saudi Arabia. The findings indicated a significantly positive relationship between job variety and commitment. Inconsistent with the proposed hypotheses, job autonomy on the other hand was found to be negatively associated with commitment whereas feedback and task identity appeared to be unrelated to commitment. The authors argued that a possible explanation for these inconsistent findings may be related to the managerial environment that prevails in Saudi Arabia. Traditionally - oriented based on bureaucratic type of management practices are seen to donate autonomy and feedback in jobs. The management style of focusing on the group rather than individual employee leads to less attachment to task identity.

\section{Organisational Commitment and Organisational Communication}

Alongside empowerment and job characteristics, another determinant that is stated to have an impact on organisational commitment is organisational communication (Chen, Silverthorne, \& Hung, 2006; Vakola \& Bouradas, 2005; Asif \& Sageant, 2000; Nijhof et al., 1998). It has been found that levels of organisational commitment are increased when employees are satisfied with the communication that flows in the organisation. Communication is an important instrument for employees to learn what is expected on them, find how to implement the work, and be aware of feedback of others on their work. The management therefore must see this communication as a fundamental means of helping to release the valuable opinions of all members. By having an effective or meaningful communication, Barret (2002) discovered two primary objectives that can be accomplished. Firstly, it can inform and educate employees at all levels regarding the company's strategy. Secondly, it can motivate and position employees to support the strategy and performance goals.

114 IJMS 17 (1), 107-128 (2010) 


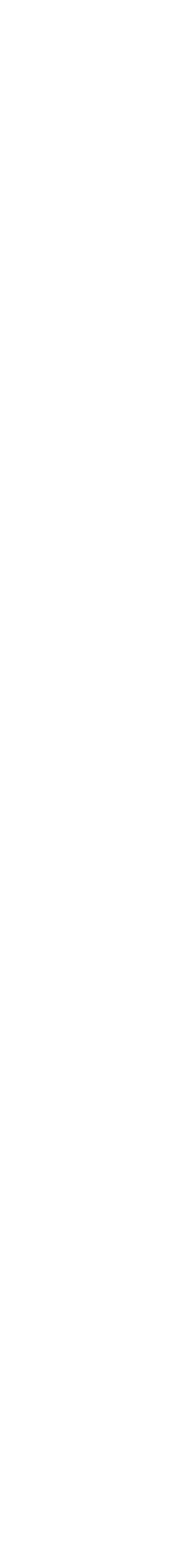

The ability of the organisation to create and expose employees to an appropriate communication environment can generate favourable outcomes (Gray \& Laidlaw, 2002), such as high work performance and productivity (Goris et al., 2000) and commitment to work (Chen et al., 2006; Thornhill, Lewis, \& Saunders 1996). A study by Putti, Aryee, and Phua (1990) attempted to investigate the relationship between attitudinal commitment and communication relationship satisfaction (CRS) disclosed a significant relationship between overall CRS with organisational commitment, suggesting that organisational member's satisfaction toward the amount of information available to them can instill their sense of belongingness and identification with the values and objectives of the organisation. A survey by Hassan and Bahtiar (2004) on employees from a large semi-government corporation and its subsidiary in Northern Peninsular Malaysia on the other hand revealed a significant positive relationship between both variables. In this study, employees who believed that they are in a higher quality exchange relationship as superiors seek their suggestions and ideas, interested in them as a person, related to them in a causal manner, and allowed them to give input on important decisions, can develop and maintain their membership with the organisation.

\section{Research Methodology}

\section{Conceptual Framework}

This conceptual framework was designed based on an extensive literature review of past research that had been conducted in and outside the country. These studies demonstrate the significant impact of empowerment, job characteristics, and organisational communication on organisational commitment (Fornes \& Rocco, 2004; Young et al., 1998; Hassan \& Bahtiar, 2004). The subsequent outcomes that are expected to occur related to this commitment include employees' willingness to engage in organisational citizenship, increase motivation, and improve their performance in work tasks.

Based on comprehensive review of issues and findings from past research that was formerly discussed in the literature review, independent variables that were proposed for the study encompassed empowerment, job characteristics, and organisational communication, while organisational commitment functions as the dependent variable. Affective, continuance, and normative commitments were also included under the organisational commitment variable. 


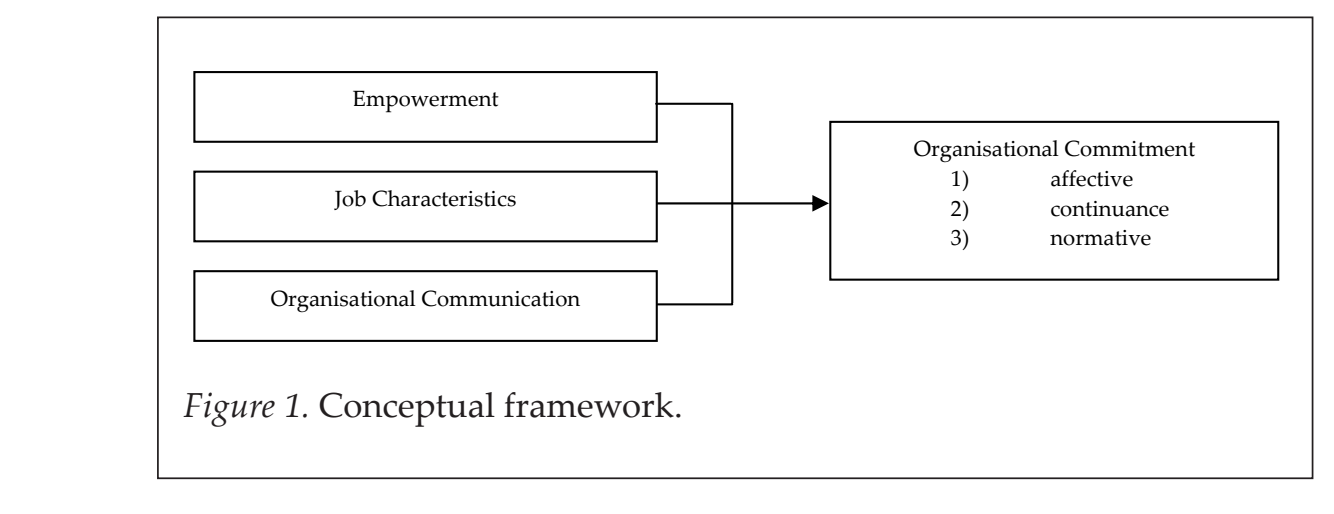

\section{Hypothesis Testing}

The relationships between empowerment, job characteristics, and organisational communication with organisational commitment that were conceptualised for the present study needed to be tested whether they do in fact hold truth. The specific hypotheses of the study are as follows:

H1: There is a significant relationship between empowerment and organisational commitment (H1a: affective, H1b: continuance, H1c: normative).

$\mathrm{H} 2$ : There is a significant relationship between job characteristics and organisational commitment (H2a: affective, H2b: continuance, H2c: normative).

H3: There is a significant relationship between organisational communication and organisational commitment (H3a: affective, H3b: continuance, H3c: normative).

\section{Survey Instruments}

A set of questionnaires for this study contained five main sections, comprising 1) Demographic Variables 2) Organisational Commitment 3) Empowerment 4) Job Characteristics, and 5) Organisational Communication. Except for - demographic variables, a five-point Likert Scale was applied for all items under organisational commitment, empowerment, job characteristics, and organisational communication variables.

\section{Section A: Demographic variables}

This section kept track on the personal information of targeted respondents. The information needed to be filled by them which comprised gender status, age level, highest educational level, organisational tenure, service group, level of income, and marital status. This section consisted of a total of nine questions regarding respondents' background.

116 IJMS 17 (1), 107-128 (2010) 


\section{Section B: Organisational commitment}

The next Section B describes respondents' perception concerning the aspect of organisational commitment. The adaptation was made based on Allen and Meyer's (1990) Three Dimensional Model of Organisational Commitment, covering affective, continuance, and normative commitments. Altogether, these three subscales provide 24 items. The first component of affective commitment measures respondents' emotional attachment toward their organisation, whereas continuance commitment clarifies employees' perception regarding the costs that they need to deal with if they choose to leave the organisation. The last component of normative commitment deals with employees' perception pertaining to their moral obligation toward the organisation.

\section{Section C: Empowerment}

Empowerment measurement was put forward in Section C. Adapted from Spreitzer's (1995) Psychological Empowerment Scale, this variable explains employees' perception regarding the aspect of empowerment. The total number of questions under the empowerment variable was 12 items.

\section{Section D: Job characteristics}

This Section D highlights the job characteristics variable. Consisting of 15 items, this variable was adapted from Hackman and Oldham's (1975) Job Diagnostic Survey.

\section{Section E: Organisational communication}

The last Section E deals with the organisational communication variable. The measurement of the variable was adapted from Downs and Hazen's (1977) Communication Satisfaction Questionnaire. Reflecting employees' satisfaction toward the existing communication in the department, the total number of questions under this variable was 34 items.

\section{Scope of the Study}

The present study attempted to examine organisational commitment from the perspective of Terengganu, Pahang and Kelantan state civil servants since not much study was done in the East Coast State. The state sector is different from federal sector, as it is under local government administration which has the right to determine programmes and policies that are most suitable for the state (Ahmad Atory, 2005). The existing differences lead to different work culture and work environment compared to the federal sector. Thus 
this study can contribute a different perspective as well as widen and deepen the knowledge by diversifying the factors that influence state civil servants' commitment. However, the findings from the study cannot be generalised on others as it is limited to the East Coast State sector only.

The selection of the respondents was carried out based on a multi - stage sampling technique. They are firstly clustered based on their departments. Seven departments which represented local administration, statutory body and local authority from each state sector were then randomly selected. The final sampling design employed was purposive sampling. This sampling design was carried out as the information needed for the study was obtained from a specific target group of management and professional, support I, and support II. The total number of population for this study was 5,024 civil servants. Referring to Krecjie and Morgan (1970), for the population size of 5,024, the minimum sample size required for the study was about 357 respondents.

From returnable questionnaires, only 250 sets of questionnaires were useful for data analysis. Out of 250 respondents that took part in the study, the majority of them were Terengganu state civil servants (104 respondents or $41.6 \%$ ), followed by Pahang and Kelantan state civil servants, with 73 respondents or $29.2 \%$ from each state.

\section{Research Findings}

\section{Reliability Analysis}

- Reliability analysis was carried out to assess the internal consistency of each of the variables used in the study. As depicted in Table 1 below, organisational communication had the highest reliability rate with Cronbach Alpha of more than 0.90, whereas organisational commitment, empowerment, and job characteristics showed internal consistency between 0.81 and 0.84 . Given these results, all variables were reviewed to have adequate levels of internal consistency since they meet the recommended standard of 0.60 (Sekaran,

(1) 2003).

- Table 1

Reliability Analysis (N=250)

\begin{tabular}{lcc}
\hline Variables & Number of Item & Alpha $(\alpha)$ \\
\hline Organisational Commitment & 23 & .8421 \\
Empowerment & 12 & .8209 \\
Job Characteristics & 15 & .8157 \\
Organisational Communication & 34 & .9137 \\
\hline
\end{tabular}

118 IJMS 17 (1), 107-128 (2010) 


\section{Descriptive Statistics}

\section{Mean scores for variables}

The mean scores were computed to answer research objective 1: To identify the level of civil servants' organisational commitment, empowerment, job characteristics, and organisational communication. As can be seen in Table 2 below, the majority of civil servants appeared to have higher levels of affective commitment (mean $=3.88$ ), as compared to continuance commitment (mean $=3.58)$ and normative commitment $($ mean $=2.92)$. Given these results, civil servants were found to be committed because of the factor they felt emotionally attached to the current department rather than tied because of the high switching costs factor associated with leaving the department or due to the feeling of moral obligation to remain in the department. Additionally, civil servants were also found to be psychologically empowered in the department (mean $=3.71, \mathrm{SD}=0.431$ ), had experienced variable job opportunities (mean $=3.51$. SD $=0.476$ ) as well as satisfied with the communication that exists in the current department $($ mean $=3.68, \mathrm{SD}=0.386)$.

Table 2

Summary of Mean Score Analysis

\begin{tabular}{ccc}
\hline Perception & Mean & Standard Deviation \\
\hline Organisational Commitment & 3.48 & 0.514 \\
$-\quad$ Affective & 3.88 & 0.558 \\
$-\quad$ Continuance & 3.58 & 0.748 \\
- Normative & 2.92 & 0.764 \\
Empowerment & 3.71 & 0.431 \\
Job Characteristics & 3.51 & 0.476 \\
Organisational Communication & 3.68 & 0.386 \\
\hline
\end{tabular}

\section{Bivariate correlation analysis}

The Pearson's Product Moment Correlation was conducted to answer research objective 2: To measure the relationship between organisational commitment (affective, continuance, and normative commitments) with empowerment, job characteristics, and organisational communication, and to test all hypotheses related to that. As illustrated in Table 3, the findings of correlation analysis had shown significantly positive relationships between organisational commitment (affective, continuance, and normative commitments) with empowerment, job characteristics, and organisational communication variables $(p<0.01)$. These results evidently supported the hypotheses H1, H1a, H1b, H1c, H2, H2a, H2b, H2c, H3, H3a, H3b, and H3c. 
Table 3

Summary of the Relationship between Dependent and Independent Variables

\begin{tabular}{lcccc}
\hline \multirow{2}{*}{ Independent Variables } & \multicolumn{3}{c}{ Dependent Variables } \\
\cline { 2 - 5 } & Org. Commitment & Affective & Continuance & Normative \\
\hline Empowerment & $0.430^{* *}$ & $0.355^{* *}$ & $0.335^{* *}$ & $0.286^{* *}$ \\
Job Characteristics & $0.416^{* *}$ & $0.364^{* *}$ & $0.245^{* *}$ & $0.336^{* *}$ \\
Org. Communication & $0.361^{* *}$ & $0.379^{* *}$ & $0.196^{* *}$ & $0.252^{* *}$ \\
\hline
\end{tabular}

Note. ${ }^{* *} p<0.01$ level (2-tailed), ${ }^{*} p<0.05$ level (2-tailed).

\section{Multiple regression analysis with stepwise procedure}

The multiple regression analysis with stepwise procedure was conducted to answer research objective 3: To determine the most dominant variable that influences organisational commitment.

\section{The Most Dominant Variable that Influences Organisational Commitment}

Organisational commitment with empowerment, job characteristics, and organisational communication

As depicted in Table 4 below, only empowerment, organisational communication, and job characteristics had stated significant influence on organisational commitment. Empowerment was discovered to be the most dominant predictor of organisational commitment $(\beta=0.241, p<0.01)$, followed by job characteristics $(\beta=0.170, p<0.05)$, and organisational communication $(\beta=0.156, p<0.05)$. Together, these three variables stated $R^{2}$ value of 0.231 , suggesting that $23.1 \%$ of the variance in organisational commitment can be explained by them.

Table 4

Stepwise Regression of Organisational Commitment ( $N=250)$

\begin{tabular}{|c|c|c|c|c|c|c|}
\hline Model & $\mathrm{R}^{2}$ & Adjusted $\mathrm{R}^{2}$ & $\begin{array}{c}\text { Unstand. } \\
\text { Beta }\end{array}$ & $\begin{array}{c}\text { Stand. } \\
\text { Beta }\end{array}$ & $\mathrm{t}$ & Sig. Value \\
\hline Model 1 & .185 & .181 & & & & \\
\hline Constant & & & 1.580 & & 6.187 & .000 \\
\hline Empowerment & & & .512 & .430 & & $.000^{* *}$ \\
\hline Model 2 & .217 & 2.10 & & & & \\
\hline Constant & & & 1.014 & & 3.292 & .001 \\
\hline Empowerment & & & .398 & .334 & 5.211 & $.000^{* *}$ \\
\hline Org. Communication & & & .270 & .203 & 3.168 & $.002^{* *}$ \\
\hline Model 3 & .231 & .221 & & & & \\
\hline Constant & & & 1.010 & & 3.301 & .001 \\
\hline Empowerment & & & .287 & .241 & 3.125 & $.002^{* *}$ \\
\hline Org. Communication & & & .208 & .156 & 2.317 & $.021^{*}$ \\
\hline Job Characteristics & & & .183 & .170 & 2.120 & $.035^{*}$ \\
\hline
\end{tabular}

Note. ${ }^{*} \mathrm{p}<0.05,{ }^{* *} \mathrm{p}<0.01$. 
The Most Dominant Variables that Influences Affective Commitment

Affective commitment with empowerment, job characteristics, and organisational communication

Based on the results in Table 5 below, only organisational communication and empowerment had shown significant influence on affective commitment. Organisational communication appeared to be the most dominant predictor of affective commitment $(\beta=0.273, p<0.01)$, followed by empowerment $(\beta=0.225, p<0.01)$. Together, these two variables stated $R^{2}$ value of 0.183 , indicating that $18.3 \%$ of the variance in affective commitment can be explained by them.

Table 5

Stepwise Regression of Affective Commitment ( $N=250)$

\begin{tabular}{|c|c|c|c|c|c|c|}
\hline Model & $\mathrm{R}^{2}$ & $\begin{array}{c}\text { Adjusted } \\
\mathrm{R}^{2} \\
\end{array}$ & $\begin{array}{c}\text { Unstand. } \\
\text { Beta }\end{array}$ & $\begin{array}{c}\text { Stand. } \\
\text { Beta }\end{array}$ & $\mathrm{t}$ & Sig. Value \\
\hline$\frac{\text { Model 1 }}{\text { Constant }}$ & .144 & .141 & 1.858 & & 5.910 & .000 \\
\hline Org. Communication & & & .549 & .379 & 6.459 & $.000^{* *}$ \\
\hline$\frac{\text { Model } 2}{\text { Constant }}$ & .183 & .177 & 1345 & & 3931 & 000 \\
\hline Org. Communication & & & $\begin{array}{r}1.445 \\
.395\end{array}$ & .273 & $\begin{array}{l}3.931 \\
4.171\end{array}$ & $.000^{* *}$ \\
\hline Empowerment & & & .292 & .225 & 3.443 & $.001^{* *}$ \\
\hline
\end{tabular}

Note. ${ }^{*} \mathrm{p}<0.05,{ }^{* *} \mathrm{p}<0.01$

The Most Dominant Variables that Influences Continuance Commitment

Continuance commitment with empowerment, job characteristics, and organisational communication

Table 6 provides the result of stepwise regression analysis between continuance commitment with overall empowerment, job characteristics, and organisational communication. With $\beta=0.335, \mathrm{p}<0.01$, only the empowerment variable was found to have a significant influence on continuance commitment. The variable had explained $11.2 \%$ of variance in continuance commitment.

Table 6

Stepwise Regression of Continuance Commitment ( $N=250)$

\begin{tabular}{lcccccc}
\hline \multicolumn{1}{c}{ Model } & $\mathrm{R}^{2}$ & Adjusted $\mathrm{R}^{2}$ & Unstand. Beta & Stand. Beta & $\mathrm{t}$ & Sig. Value \\
\hline Model 1 & .112 & .109 & & & & \\
Constant & & & 1.416 & & 3.646 & .000 \\
Empowerment & & & .582 & .335 & 5.598 & $.000^{* *}$ \\
\hline
\end{tabular}

Note. ${ }^{*} \mathrm{p}<0.05,{ }^{* *} \mathrm{p}<0.01$. 


\section{The Most Dominant Variables that Influences Normative Commitment}

\section{Normative commitment with empowerment, job characteristics, and organisational communication}

Table 7 below illustrates the result of stepwise regression analysis between normative commitment with overall empowerment, job characteristics, and organisational communication. Based on the result, only job the characteristics variable had significant influence on normative commitment $(\beta=0.336, \mathrm{p}<0.01)$. The variable had explained $11.3 \%$ of variance in normative commitment.

Table 7

Stepwise Regression of Normative Commitment ( $\mathrm{N}=250)$

\begin{tabular}{lcccccc}
\hline \multicolumn{1}{c}{ Model } & $\mathrm{R}^{2}$ & Adjusted $\mathrm{R}^{2}$ & Unstand. Beta & $\begin{array}{c}\text { Stand. } \\
\text { Beta }\end{array}$ & $\mathrm{t}$ & $\begin{array}{c}\text { Sig. } \\
\text { Value }\end{array}$ \\
\hline Model 1 & .113 & .109 & & & & \\
Constant & & & 1.027 & & 3.024 & .003 \\
Job Characteristics & & & .538 & .336 & 5.609 & $.000^{* *}$ \\
\hline
\end{tabular}

Note. ${ }^{*} \mathrm{p}<0.05,{ }^{* *} \mathrm{p}<0.01$.

\section{Discussion and Conclusion}

In conclusion, the present study reports on the investigation of the relationship between empowerment, job characteristics, and organisational communication with organisational commitment. The findings were considered to have made a significant contribution by adding information to the management literature to create a better understanding of the influence of empowerment, job characteristics, and organisational communication regarding state civil servants' commitment to the department. Overall, the civil servants were discovered to be emotionally attached to the department, psychologically empowered in the workplace, had been given a chance to experience variable opportunity in their jobs, and they were satisfied with the communication environment in the department.

Congruent with previous studies by Batnagar (2005), Che Su et al. (2004) and Dunham et al. (1994), the findings demonstrated the significant relationship between empowerment, job characteristics, and organisational communication with civil servants' organisational commitment (affective, continuance, and normative commitments).

Of all the predictor's variables, empowerment appeared to be the most dominant variable in influencing civil servants' organisational commitment

122 IJMS $17(1), 107-128(2010)$ 


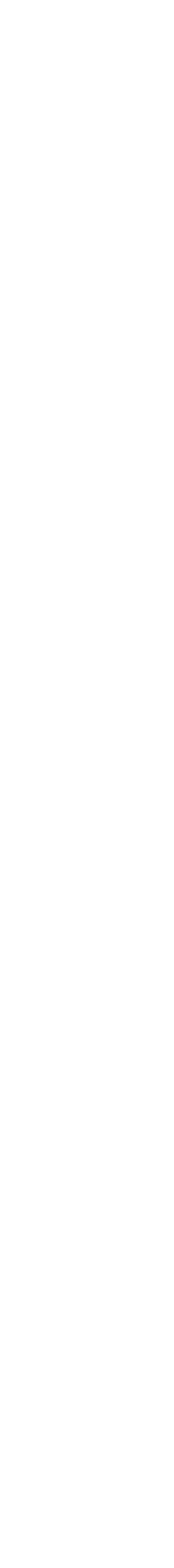

to the department. According to Fornes and Rocco (2004), employees' commitment can occur through empowerment as it can produce psychological states which in turn contribute to positive consequences for the organisation, such as willingness to engage in organisational citizenship, manifestation of extra role performance, promotion of satisfaction in job, and encouragement of motivation.

Next, organisational communication emerged to be the most dominant variable in predicting civil servants' affective commitment. In line with the study by Putti et al. (1990), the amount of information people receive about the work environment and the degree to which they can actively participate in communication with other members in the organisation were found to be positively related to employees' commitment to the organisation.

Meanwhile, civil servants with continuance commitment tend to be mostly influenced by the factor of empowerment. The civil servants who perceived themselves as psychologically empowered would exhibit more positive consequences on civil servants' continuance commitment. Consistent with Batnagar (2005) and Allen and Meyer (1990), the abilities and capabilities to perform work activities as well as having mastered the skills necessary for the job, these investments that came along with year of employment tend to tie civil servants to the department. Employees with continuance commitment were found to be attached to the organisation because of the investments that they had made over the years that could not be transferable to new organisation. These investments include organisation-based skills, position, status, and years of employment.

For civil servants with normative commitment, they were found to be best predicted by the job characteristics factor. Civil servants who valued a stable set of job dimensions appeared to be more obliged to the department. Stallworth (2003) stated that one of the factors that could create a sense of obligation within employees was the receipt of benefit received by them. For the present study, it is suggested that variable opportunities provided to civil servants would inculcate a sense of obligation among civil servants to commit to the department.

\section{Managerial Implications}

These findings had imposed potential implications for management to review for future plans in order for them to increase civil servants' commitment to the department. Referring to the results, it is therefore suggested for the management to focus on the communication aspect in the organisation. The issue of communication is critical for civil servants as they

IJMS 16 (2), 107-128 (2010) 
need to know the feedback concerning their work as it can assist them to see the direction of the organisation and how they can fit in and play their roles in the department. A study by Thornhill et al. (1996) showed that the well formulated communication by the organisation may promote employees' commitment to pursue high quality. From the findings, employees who perceived the positive effort made by the management to keep them well informed tend to feel part of the organisation, believed it was a good place to work, and had a bright future. Contrary to that, uninformed employees were found to be less committed to the organisation.
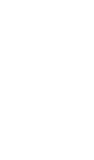

(1)

-

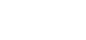

ren

$\square$

$\square$

(1)

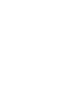

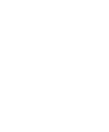

몸
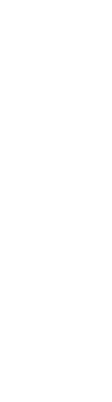

Guided by the studies of Asif and Sargeant (2000) and Thornhill et al. (1996), one of the efforts that can be taken by the management to instill civil servants emotional attachment to the organisation is by having effective communication in the department. According to the authors, this effective communication should demonstrate the open, interactive, persuasive, and well co-coordinated communication between upper management and the civil servants. The culture of effective communication may be enhanced by encouraging horizontal and vertical communication flows in the department as well as balancing the need to communicate formally and by informal and personal forms of communication.

Other different strategies also need to be implemented by the management on those who show continuance commitment to the department. Associated with the cost of quitting, civil servants are said to be committed because of the factor of the investments that have been made by them over the years which cannot be transferable to another workplace. With these accumulated investments, it would be difficult for civil servants to leave the department even though they want to do so. The reluctance of civil servants to leave however is unbeneficial for the department as civil servants are expected to contribute the minimum in work, an amount they considered sufficient to stay (Manogran, 1996).

Based on the findings, civil servants with continuance commitment are strongly influenced by the factor of empowerment. The management may improve civil servants' continuance commitment level by fostering the environment in the department that can facilitate to create the entire component of empowerment (Laschinger, Heather, Finegan, \& Shamian, 2001; Spreitzer, 1995). These include providing civil servants sufficient access to support, resources, as well as access to the information about the mission of the department and information to get their work done. These easy accesses should cover the access to the strategic information necessary to complete the work well, understand top management's vision, and the goal of the department. The importance of having these accessibilities can be seen in the study by Liu et al. (2006) who discovered that the factors of 


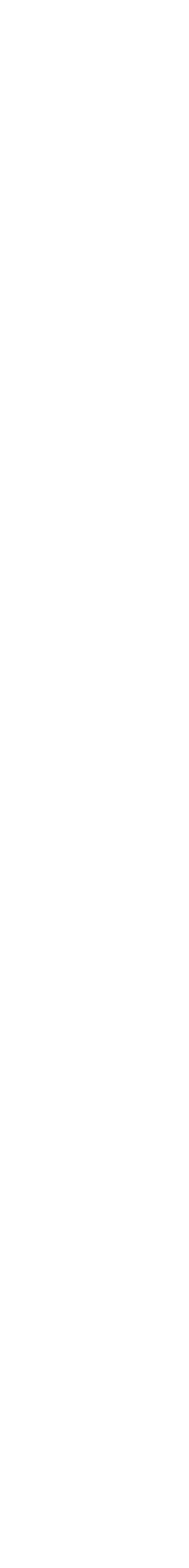

access to opportunity and resources had enhanced self efficacy of employees to feel empowered, fostered their motivation as well as commitment which eventually led to increase their work performance and effectiveness.

The weaker normative commitment on the other hand may affect civil servants' loyalty and devotion to the department. Given the low normative commitment result, the remaining civil servants were found not to be attached to the feeling of obligation to the department. The low impart on the value staying on to one organisation among civil servants is one of the possible explanations for this situation to occur. It may therefore benefit the department to increase civil servants' normative commitment as it reflects their loyalty to the department, the willingness to expand their effort in their accomplishment, and intentions to continue employment there (Ackfeldt \& Coote, 2002).

Since the results showed that civil servants with normative commitment are best predicted by the factor of job characteristics, it is therefore suggested for the management to design and improve the job description of civil servants. The management may establish work that can give a feeling of having control and influence over departmental outcomes to inspire civil servants' loyalty and devotion to the department. Additionally, the management should let civil servants more frequently be on their own to do work, act independently, as well as accomplished their work from the beginning to the end. By giving civil servants sufficient autonomy in work, it will liberate their creativity and talents to the fullest and make them happier with their work, which in turn may increase their commitment to the department (Mohd Zain \& Khairul Anwar, 2000). Sufficient training should also be provided by the management to civil servants in order for them to utilise the skills needed to perform the work. According to Stallworth (2003), the receipt of benefits such as training can create a sense of obligation in employees.

\section{References}

Ackfeldt, A.L., \& Coote, L.V. (2002). A study of organisational citizenship behaviours in a retail organisation. Australia: Business School. University of Queensland.

Ahmad Atory Hassan. (2005). Administrative reform in local government system in Malaysia. Rekayasa, 9-34.

Allen, N.J., \& Meyer, J.P. (1990). The measurement and antecedents of affective, continuance and normative commitment to the organization. Journal of Occupational Psychology, 63, 1-18.

Asif, S., \& Sargeant, A. (2000). Modelling internal communications in the financial services sector. European Journal of Marketing, 34(3/4), 299-317.

Barret, D.J. (2002). Change communication: Using strategic employee communication to facilitate major change. Corporate Communications: An International Journal, 7(4), 219-231.

IJMS 16 (2), 107-128 (2010) 
Batnagar, J. (2005). The power of psychological empowerment as an antecedent to organisational commitment in Indian Managers. Human Resource Development International, 8(4), 419-433.

Bhuain, S.N., Al-Shammari, E.S., \& Jefri, O.A. (2001). Work related attitudes and job characteristics of expatriates in Saudi Arabia. Thunderbird International Business Review, 43(1), 21-30.

Brewer, G. (1997, February). Secrets to building employee loyalty. World Executive's Digest, 44-46.

Che Su Mustafa. (2004). Keberkesanan komunikasi organisasi: Satu analisis multidimensi. International Journal Malaysian Studies, 11(2), 91-122.

Chen, J.C., Silverthorne, C., \& Hung, J.Y. (2006). Organization of accounting professionals in Taiwan and America. Leadership and Organization Development Journal, 27(4), 242-249.

Colbert, A. E., \& Kwon, I. G. (2000). Factors related to the organizational commitment of college and university auditors. Journal of Managerial Issues, 12(4), 484-501.

Dee, J.R., Henkin, A.B., \& Duemer, L. (2003). Structural antecedents and psychological correlates of teacher empowerment. Journal of Educational Administration, 41(3), 257-277.

Downs, C., \& Hazen, M. (1977). A factor-analytic study of communication satisfaction. Journal of Business Communication, 14(3), 63-74.

Dunham, R.B., Grube, J.A., \& Castaneda, M.B. (1994). Organisational commitment: The utility of an integrative definition. Journal of Applied Psychology, 79(3), 370-380.

Fornes, S.L., \& Rocco, T.S. (2004). Commitment elements reframed (antecedents and consequences) for organisational effectiveness. Florida International University, 19(3), 391-397.

Goris, J. Vaught, B., \& Pettit, J. (2000). Effects of communication direction on job performance and satisfaction: A moderated regression analysis. The Journal of Business Communication, 37(4), 348-368.

Gray, J., \& Laidlaw, H. (2002). Part-time employment and communication satisfaction in an Australian retail organisation. Employee Relations, 24(2), 211-228.

Hackman, J.R., \& Oldham, G.R. (1975). Development of the job diagnostic survey. Journal of Applied Psychology, 60(2), 159-170.

Hassan, A.B., \& Bahtiar, M. (2004). Dimensions of supervisory communication and organizational commitment: A case study of a Malaysian organisation. The Malaysian Journal of Language and Communication, 1(1), 1-19.

Hunt, O., Tourish, D., \& Hargie, O. D. W. (2000). The communication experiences of education managers: Identify strengths, weaknesses and critical incidents. The International Journal of Educational Management, 14(3), 120-129.

Ishak, T.K. (2005, June 23). In Utusan Malaysia. Sebahagian besar kakitangan tidak ikhlas. Retrieved July 24, 2006, from http://www.utusan.com.my.

Jones, P. P., Palmer, J., Whitehead, D., \& Osterwell, C. (1996). Performance through people. Empowerment in Organizations, 4(4), 23-27.

Kamarul Zaman, A., \& Raida, A.B. (2003). The association between training and organisational commitment among white-collar workers in Malaysia. International Journal of Training and Development, 7(3), 166185. 
Krejcie, R., \& Morgan, D. (1970). Determining sample size for research activities. In Sekaran, U. (2003). Research methods for business. A skill building approach (4th ed.). United States of America: John Wiley and Sons.

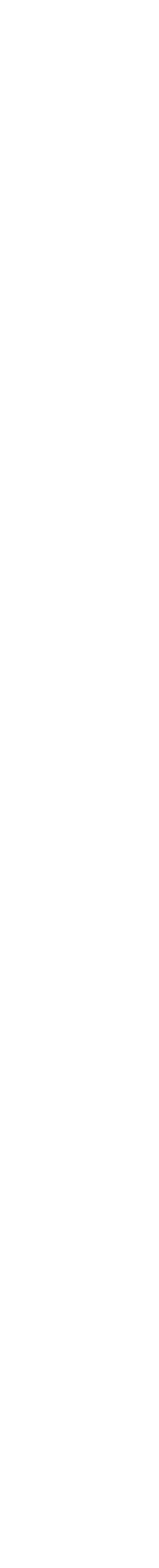

Kwon, I.G., \& Banks, D.W. (2004). Factors related to the organisational and professional commitment of internal auditors. Managerial Auditing Journal, 19(5), 606-622.

Laschinger, S., Heather, K., Finegan, J., \& Shamian, J. (2001). The impact of workplace empowerment, organisational trust on staff nurses' work satisfaction and organizational commitment. Health Management Review, 26(3), 7-24.

Liu, M.M.A., Fellows, R., \& Chiu, W.M. (2006). Work empowerment as an antecedent to organisational commitment in the Hong Kong Quantity Surveying Profession. Surveying and Built Environment, 17(2), 63-72.

Malaysia. (2005). Productivity Report. Enhancing Malaysia's competitiveness through productivity and quality initiatives. National Productivity Corporation.

Manogran, P. (1996, July). The committed employee. Magazine of Khidmat, 20-22.

Mathieu, J.E., \& Zajac, D.M. (1990). A review and meta-analysis of the antecedents, correlates, and consequences of organisational commitment. Psychological Bulletin, 108(2), 171-194.

Mohd Najib, A.R. (2006, August 21). Strive for civil service delivery beyond the ordinary. Bernama.

Mohd Zain, I., \& Khairul Anwar, S. (2000). Organisational behaviour. Shah Alam: Mara University of Technology, 67-68.

Mohtar, A. (2004). Integriti dijulang, perkhidmatan awam terbilang. Majlis Perhimpunan Bulanan JPA. Putrajaya.

Mowday, R., Steers, R.M., \& Porter, L. (1979). The measurement of organisational commitment. Journal of Vocational Behaviour, 14, 224-247.

Newstrom, J.W., \& Davis, K. (2002). Organizational behaviour: Human behaviour at work (11th ed.). Boston: McGraw Hill.

Nijhof, W.J., De Jong, M.J., \& Beukhof, G. (1998). Employee commitment in changing organizations: an exploration. Journal of European Industrial Training, 22(6), 243-248.

Nixon, B. (1994). Developing an empowering culture in organizations. Empowerment in Organizations, 2(1), 14-24.

Putti, J.M., Aryee, S., \& Phua, J. (1990). Communication relationship satisfaction and organizational commitment. Group and Organization Studies, 15(1), 44-52.

Rajendran, M., \& Raduan, C.R. (2005). Antecedents and outcomes of organizational commitment among Malaysian engineers. American Journal of Applied Sciences, 2(6), 1095-1100.

Razali, M.Z. (1999). Organisational climate and communication climate as predictors of commitment to the organisation: A case study. Malaysian Management Research, 1-7.

Rousseau, D.M. (1998). Why workers still identify with organizations. Journal of Organizational Behavior, 19, 217-233. In Fornes, S. L., and Rocco, T. S. (2004). Commitment elements reframed (antecedents and

IJMS 16 (2), 107-128 (2010) 
consequences) for organizational effectiveness. Florida International University, 19(3), 391-397.

Sekaran, U. (2003). Research methods for business. A skill building approach (4th ed). United States of America: John Wiley and Sons.

Sheldon, M.E. (1971). Investment and involvement as mechanisms producing commitment to the organization. Administrative Science Quarterly, 16, 142-150.

Shortland, S. (2005). Work-life balance: The impact of policy and practice on the human resource function. New York: Industrial Relations Counselor.

Spreitzer, G.M. (1995). Psychological empowerment in the workplace: Dimensions, measurement, and validation. Academy of Management Journal, 38(5), 1442-1465.

Stallworth, H.L. (2003). Mentoring, organizational commitment and intentions to leave public accounting. Managerial Auditing Journal, 18(5), 405-418.

Thornhill, A., Lewis, P., \& Saunders, M.N.K. (1996). The role of employee communication in achieving commitment and quality in higher education. Quality Assurance in Education, 4(1), 12-20.

Ugboro, I.O. (2006). Organizational commitment, job redesign, employee empowerment and intent for quit among survivors of restructuring and downsizing. Journal of Behavioral and Applied Management, 7(3), 232-252.

Utusan Malaysia (2005, June 23). Sebahagian besar kakitangan tidak ikhlas. Retrieved on July 24, 2006, from, http://www.utusan.com.my.

Vakola, M., \& Bouradas, D. (2005). Antecedents and consequences of organisational silence: An empirical investigation. Employee Relations, 27(5), 441-458.

Wiener, Y. (1982). Commitment in organisations: A normative view. Academy of Management Review, 7(3), 418-428.

Young, B.S., Worchel, S., \& Woehr, D. (1998). Organizational commitment among public service employees. Public Personnel Management, 27(3), 339-349.

Zakaria, I. (2004). Organisational commitment and the new workforce: A review of antecedents, outcomes and relevance. IJMS, 11(Special Issue), 1-28. 